\title{
Luteolytic effect of 13,14-dihydro-PGF-2 $\alpha$ in heifers
}

\author{
R. A. Milvae and W. Hansel \\ Department of Physiology, New York State College of Veterinary Medicine, Cornell University, \\ Ithaca, New York 14853, U.S.A.
}

\begin{abstract}
Summary. Holstein heifers (4/group) were injected intramuscularly with $0,5,10$ or 25 mg 13,14-dihydro-PGF-2 $\alpha$ on Day 10 of the oestrous cycle. Complete luteolysis and precocious oestrus occurred in 3 of 4 heifers receiving $25 \mathrm{mg}$ and 1 of 4 receiving $10 \mathrm{mg}$ 13,14-dihydro-PGF-2 $\alpha$ injected i.m. These features were not affected in heifers

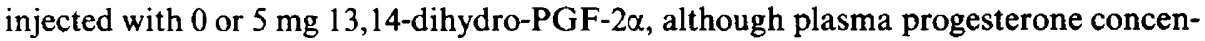
trations were depressed in all treated heifers within $75 \mathrm{~min}$. LH concentrations were elevated between 5 and $8 \mathrm{~h}$ after 13,14-dihydro-PGF- $2 \alpha$ in all treated heifers. The addition of 13,14-dihydro-PGF- $2 \alpha$ to dispersed bovine luteal cells did not affect progesterone accumulation during a 2 -h period. These results suggest that $13,14-$ dihydro-PGF- $2 \alpha$ may play a role in PGF- $2 \alpha$-induced luteolysis.
\end{abstract}

\section{Introduction}

Although the luteolytic effects of exogenous prostaglandin (PG) F-2 $\alpha$ in cattle have been extensively studied (Hansel \& Beal, 1979), little information is available concerning the effects of PGF- $2 \alpha$ metabolites on bovine corpus luteum (CL) function.

In the rabbit, 13,14-dihydro-PGF-2 $\alpha$, the $\Delta^{\prime 3}$-PG-reductase product of PGF-2 $\alpha$, was reported to be a more potent luteolytic compound than PGF-2 $\alpha$ (Kehl \& Carlson, 1981). In rat ovarian homogenates, the major metabolite of PGF- $2 \alpha$ was reported to be 13,14 -dihydro-PGF- $2 \alpha$ (Aizawa, Inazu \& Kogo, 1980).

The present experiments were conducted to determine the in-vivo and in-vitro effects of $13,14-$ dihydro-PGF- $2 \alpha$, upon the function of the bovine CL.

\section{Materials and Methods}

\section{In-vivo experiments}

Sixteen (16) Holstein heifers having oestrous cycles of normal lengths were randomly assigned to receive one of the following treatments on Day 10 of the oestrous cycle. Four heifers each were

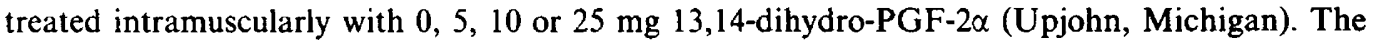
13,14-dihydro-PGF-2 $\alpha$ was greater than $95 \%$ pure (personal communication, J. E. Pike, Upjohn). The vehicle consisted of $10 \mu \mathrm{l}$ absolute ethanol in $3.0 \mathrm{ml} \mathrm{0.9 \%}(\mathrm{w} / \mathrm{v}) \mathrm{NaCl}$. Blood samples $(15 \mathrm{ml})$ were collected via jugular venepuncture into tubes containing $0.2 \mathrm{ml}$ saturated sodium citrate before and at 15 -min intervals for $3.5 \mathrm{~h}$ after treatment. Additional samples were collected 4, 5, 6, 7, $8,10,12,24,48$ and $72 \mathrm{~h}$ after treatment. Aliquots of plasma were made in triplicate within $2 \mathrm{~h}$ of collection and stored at $-20^{\circ} \mathrm{C}$.

Heifers were observed twice daily for signs of standing oestrus, beginning $24 \mathrm{~h}$ after treatment. 
Progesterone concentrations (Beal, Milvae \& Hansel, 1980) were determined in all samples by radioimmunoassay (RIA). Pooled plasma samples were run in each assay and the coefficient of variation for the progesterone RIA based on these pools was $8 \cdot 1 \%(n=16)$.

Oestradiol-17 $\beta$ concentrations were determined by the Micromedic RIA kit (Horsham, Pennsylvania) using ${ }^{125}$ I-labelled oestradiol-17 $($ England, Niswender \& Midgley, 1974) in samples collected before and at l-h intervals until $8 \mathrm{~h}$, and at 10,12 and $24 \mathrm{~h}$ after treatment. The antiserum had a cross-reactivity of $26 \%$ with oestradiol- $17 \alpha$; and $<1 \%$ with other steroids tested. The assay had a sensitivity of $3 \mathrm{pg} / \mathrm{ml}$ and a $\mathrm{H}_{2} \mathrm{O}$ or solvent blank of $0.7 \mathrm{pg} /$ tube. Duplicate $2 \mathrm{ml}$ aliquots of plasma were extracted twice with diethyl ether; the extracts were dried under $\mathrm{N}_{2}$, resuspended in benzene : methanol $(85: 15, \mathrm{v} / \mathrm{v})$ and run through a $4 \mathrm{~cm} \mathrm{LH}-20$ column to remove interfering lipids. $\left[{ }^{3} \mathrm{H}\right]$ Oestradiol was added to each sample to determine extraction efficiency which averaged $78 \%$ (range of $65-88 \%)$. Assays $(n=4)$ were run at plasma volumes of $1 \mathrm{ml}(4.9 \mathrm{pg}), 2 \mathrm{ml}(9 \cdot 2 \mathrm{pg})$ and 3 $\mathrm{ml}(15 \cdot 2 \mathrm{pg})$ to verify parallelism. The intra- and inter-assay $(n=4)$ coefficients of variation were $11 \cdot 2$ and $14.3 \%$, respectively.

The LH RIA (Niswender, Reichert, Midgley \& Nalbandov, 1969) used anti-ovine LH (GDNNo. 15) generously supplied by Dr G. D. Niswender; highly purified bovine LH (supplied by Dr L. Reichert) was used for iodination material; and bovine LH for standards (NIH-B9-LH). The sensitivity of the assay was approximately $0.1 \mathrm{ng} / \mathrm{ml}$ and the interassay coefficient of variation was $6.9 \%(n=8)$.

The effects of treatment on plasma hormone concentrations were statistically evaluated by split-plot analysis of variance for repeated measurements (Gill \& Hafs, 1971).

\section{In-vitro experiments}

Corpora lutea $(n=5)$ were enucleated from heifers on Day 10 of the oestrous cycle and immediately placed in cold $\left(4^{\circ} \mathrm{C}\right)$ Medium 199 . Dispersed cell preparations were made and the concentrations of viable cells were determined by counting those cells excluding Trypan Blue (Simmons, Caffrey, Phillips, Abel \& Niswender, 1976).

Incubations were conducted with $10^{6}$ viable cells $/ \mathrm{ml}$ at $37^{\circ} \mathrm{C}$ in a Dubnoff metabolic shaker under an atmosphere of $95 \% \mathrm{O}_{2}-5 \% \mathrm{CO}_{2}$. After a 30-min pretreatment period, an aliquot of the medium and cells $(0 \mathrm{~h})$ was removed and the following substances were added in a $10 \mu \mathrm{l}$ volume of Medium 199: 5 ng LH (NIH-LH-B9), 10 ng 13,14-dihydro-PGF-2 $\alpha, 100$ ng 13,14-dihydro-PGF-2 $\alpha$, and $1000 \mathrm{ng} 13,14$-dihydro-PGF-2 $\alpha$. There were 5 replicates/CL and control cultures received Medium 199 only. After $2 \mathrm{~h}$ a second aliquot was removed. Net progesterone accumulation, representing progesterone in medium plus cells, was the difference between concentrations at 0 and $2 \mathrm{~h}$. These data were analysed by Student $t$ tests.

\section{Results}

In-vivo experiments

Complete luteolysis and precocious oestrus occurred in 3 of 4 heifers receiving $25 \mathrm{mg}$ and 1 of 4

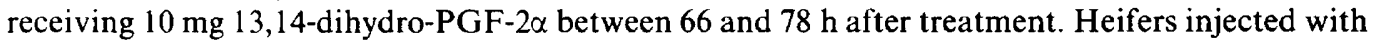

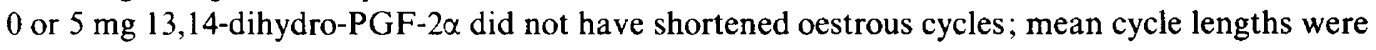
$21 \cdot 5$ days.

Mean jugular plasma progesterone concentrations were depressed $(6 \cdot 1 \pm 0 \cdot 4$ to $3 \cdot 3 \pm 0 \cdot 2$ $\mathrm{ng} / \mathrm{ml}, P<0.05$ ) in each treatment group within 75 min of treatment (Text-figs $1 \mathrm{a}-\mathrm{d}$ ). Responses uniformly consisted of an initial decrease $(0-1.5 \mathrm{~h})$ followed by a rise $(1.5-3 \mathrm{~h})$, and then a decline (3-6 h) in plasma progesterone concentrations. Between 24 and $72 \mathrm{~h}$ progesterone concentrations continued to fall in those heifers with shortened cycles, but rose in those that did not have shortened cycles. 


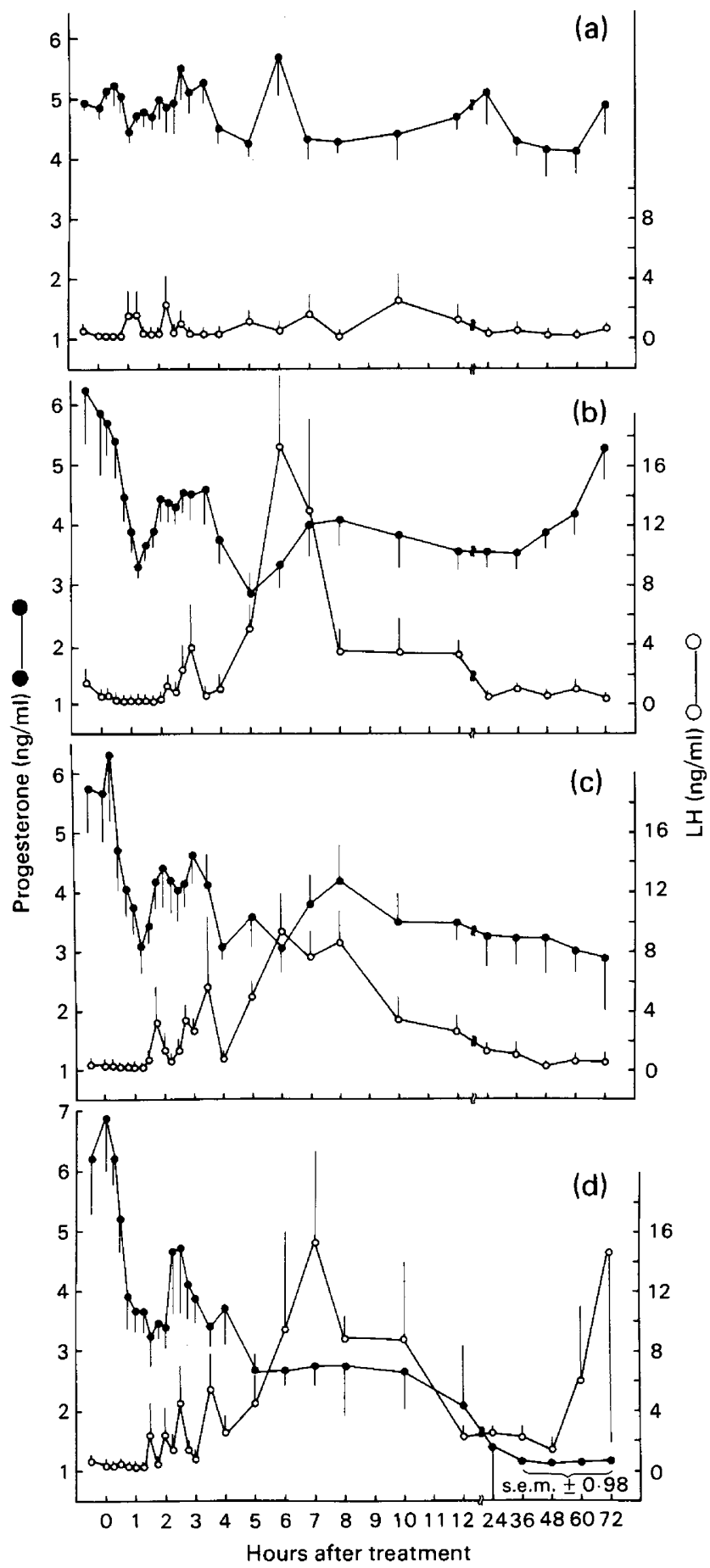

Text-fig. 1. Mean \pm s.e.m. plasma progesterone and LH concentrations in heifers treated on

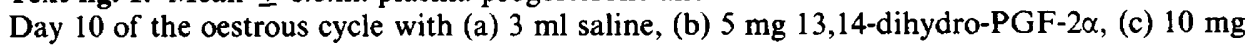
13,14-dihydro-PGF-2 $\alpha$ and (d) $25 \mathrm{mg} \mathrm{13,14-dihydro-PGF-2 \alpha .}$ 
All groups of treated heifers had elevated LH concentrations $(P<0.05)$ between 5 and $8 \mathrm{~h}$ after treatment (Text-figs la-d). Peak LH concentrations varied between 7.8 and $31.4 \mathrm{ng} / \mathrm{ml}$ in individual heifers. Small transient increases in plasma LH concentrations occurred 2-3 h before the LH peaks in all treated heifers. Large 'preovulatory-like' peaks occurred in the presence of plasma progesterone concentrations of $\sim 3 \mathrm{ng} / \mathrm{ml}$.

There were no differences $(P>0.05)$ in the size or duration of LH peaks amongst heifers treated with 13,14-dihydro-PGF-2 $\alpha$.

The 4 heifers having shortened oestrous cycles again had elevated $\mathrm{LH}$ concentrations between 60 and $72 \mathrm{~h}$. These were assumed to be the preovulatory LH surges associated with the induced precocious oestrus. None of these treatments affected the lengths of subsequent oestrous cycles.

Mean plasma oestradiol- $17 \beta$ concentrations ranged from 2.6 to $10.5 \mathrm{pg} / \mathrm{ml}$ and were unaffected by treatment with any dose of 13,14-dihydro-PGF- $2 \alpha$ when compared to control heifers.

\section{In-vitro experiments}

Accumulated progesterone concentrations ( $\mathrm{ng} / 10^{6}$ cells) were unaffected by $10 \mathrm{ng}(132 \pm 22)$, $100 \mathrm{ng}(138 \pm 38)$ or $1000 \mathrm{ng}$ (155 \pm 51) 13,14-dihydro-PGF-2 $\alpha$ when compared to control tissue $(112 \pm 18)$. As expected, $\mathrm{LH}$ resulted in a large stimulation of progesterone production $(417 \pm 81$, $P<0.01)$.

\section{Discussion}

The luteolytic effects of 13,14 -dihydro-PGF- $2 \alpha$ in this study are similar to those reported with PGF- $2 \alpha$ in cattle (Hafs, Louis, Noden \& Oxender, 1974). Treatment with 13,14-dihydro-PGF- $2 \alpha$ was as effective as that with equivalent amounts of PGF- $2 \alpha$, but not more potent than PGF-2 $\alpha$, as was reported for the rabbit (Kehl \& Carlson, 1981). Plasma progesterone concentrations fell approximately $50 \%$ within $1 \mathrm{~h}$, and then a further reduction to near basal progesterone levels occurred by $24 \mathrm{~h}$ in those heifers undergoing luteolysis and precocious oestrus. In those heifers not having a shortened oestrous cycle, plasma progesterone concentrations fell rapidly but recovered by $24 \mathrm{~h}$ after treatment.

We have previously reported (Shemesh \& Hansel, 1975; Lukaszewska \& Hansel, 1980; Milvae $\&$ Hansel, 1980) that there are increased uterine venous PGF- $2 \alpha$ concentrations late in the bovine oestrous cycle and after oxytocin injections early in the cycle. However, these large increases in uterine venous PGF- $2 \alpha$ concentrations were never reflected in the ovarian arterial levels of PGF$2 \alpha$. It is possible that some of the PGF- $2 \alpha$ released was converted into 13,14-dihydro-PGF- $2 \alpha$, which does not react with our PGF- $2 \alpha$ antiserum, and consequently was not measured. Data are not available on the rates of uterine PGF-2 $\alpha$ 13,14-reduction and 15-oxidation in the cow, although 13,14-dihydro-PGF-2 $\alpha$ has been detected in other species (Hamberg \& Samuelsson, 1971; Granstrom, 1972; Aizawa et al., 1980).

The large increases in plasma $\mathbf{L H}$ concentrations occurring in all heifers $5-10 \mathrm{~h}$ after receiving 13,14-dihydro-PGF- $2 \alpha$ differ from results obtained with PGF- $2 \alpha$. Louis, Stellflug, Tucker \& Hafs (1974) reported a 2 -fold or greater increase in $\mathrm{LH}$ concentrations $1.5-6 \mathrm{~h}$ after intramuscular injections of 15-60 mg PGF- $2 \alpha$ but these results were not consistent. In our study, all heifers that received 13,14-dihydro-PGF-2 $\alpha$ had large sustained rises in $\mathrm{LH}$ levels that were not dosedependent, but rather were coincident with the precipitous decline in plasma progesterone concentrations.

In previous studies it was reported that addition of PGF- $2 \alpha$ to dispersed bovine luteal cells or slices had no effect on progesterone accumulation (Hixon \& Hansel, 1979) or increased progesterone accumulation (Speroff \& Ramwell, 1970; Hansel, Concannon \& Lukaszewska, 1973). Hixon \& Hansel (1979) reported an additive effect of PGF- $2 \alpha$ and LH on increasing production of 
progesterone by dispersed bovine luteal cells. We suggested that the lack of an inhibitory effect of PGF- $2 \alpha$ in the present study may have been due to an inability of luteal tissue to convert the added PGF- $2 \alpha$ to 13,14-dihydro-PGF- $2 \alpha$. This appears not to be the case, since the addition of $13,14-$ dihydro-PGF- $2 \alpha$ to bovine dispersed luteal cells was without effect on progesterone production.

The luteolytic efficacy of 13,14 -dihydro-PGF- $2 \alpha$ in vivo suggests that it may play a role in PGF$2 \alpha$-induced luteolysis in the cow.

We thank Dr J. E. Pike, Upjohn Co., Kalamazoo, Michigan, for the gift of 13,14-dihydro-PGF$2 \alpha$ and Dr G. D. Niswender for the LH antiserum. This research was supported by grant from the National Institutes of Health (HD 06718).

\section{References}

Aizawa, Y., Inazu, N. \& Kogo, H. (1980) Catabolism of prostaglandin $\mathrm{F}-2 \alpha$ in the rat ovary: differences between ovarian and uterine tissues. Prostaglandins 20, 95-103.

Beal, W.E., Milvae, R.A. \& Hansel, W. (1980) Oestrous cycle length and plasma progesterone concentrations following administration of prostaglandin F- $2 \alpha$ early in the bovine oestrous cycle. J. Reprod. Fert. 59, 393396.

England, B.G., Niswender, G.D. \& Midgley, A.R. (1974) Radioimmunoassay of estradiol $17-\beta$ without chromatography. J. clin. Endocr. Metab. 38, 42-50.

Gill, J.L. \& Hafs, H.D. (1971) Analysis of repeated measurements of animals. J. Anim. Sci. 33, 331-336.

Granstrom, E. (1972) On the metabolism of PGF- $2 \alpha$ in female subjects. Eur. J. Biochem. 27, 462-469.

Hafs, H.D., Louis, T.M., Noden, P.A. \& Oxender, W.D. (1974) Control of the estrous cycle with prostaglandin F-2 $\alpha$ in cattle and horses. J. Anim. Sci. 38, Suppl. 1, 10-21.

Hamberg, M. \& Samuelsson, B. (1971) Metabolism of $\mathrm{PGE}_{2}$ in guinea pig liver. J. biol. Chem. 246, 10731077.

Hansel, W. \& Beal, W.E. (1979) Ovulation control in cattle. In Animal Reproduction, pp. 91-110. Ed. H. D. Hawk. Allanheld, Osmun \& Co., Montclair, New Jersey.

Hansel, W., Concannon, P.W. \& Lukaszewska, J. (1973) Corpora lutea of the large domestic animals. Biol. Reprod. 8, 222-245.

Hixon, J.E. \& Hansel, W. (1979) Effects of prostaglandin F-2 $\alpha$, estradiol and luteinizing hormone in dispersed cell preparations of bovine corpora lutea. In Ovarian,
Follicular and Corpus Luteum Function, pp. 613-619. Eds C. P. Channing, J. M. Marsh \& W. A. Sadler. Plenum, New York.

Kehl, S.J. \& Carlson, J.C. (1981) Assessment of the luteolytic potency of various prostaglandins in the pseudopregnant rabbit. J. Reprod. Fert. 62, 117-122.

Louis, T.M., Stellflug, J.N., Tucker, H.A. \& Hafs, H.D. (1974) Plasma prolactin, growth hormone, luteinizing hormone and glucocorticoids after prostaglandin F- $2 \alpha$ in heifers. Proc. Soc. exp. Biol. Med. 147, 128133.

Lukaszewska, J. \& Hansel, W. (1980) Corpus luteum maintenance during early pregnancy in the cow. $J$. Reprod. Fert. 59, 485-493.

Milvae; R.A. \& Hansel, W. (1980) Concurrent uterine venous and ovarian arterial prostaglandin $F$ concentrations in heifers treated with oxytocin. J. Reprod. Fert. 60, 7-15.

Niswender, G.D., Reichert, L.E., Midgley, A.R. \& Nalbandov, A.V. (1969) Radioimmunoassay for bovine and ovine luteinizing hormone. Endocrinology 84, 1166-1173.

Shemesh, M. \& Hansel, W. (1975) Levels of prostaglandin F (PGF) in bovine endometrium, uterine venous, ovarian arterial and jugular plasma during the oestrous cycle. Proc. Soc. exp. Biol. Med. 148, $123-126$

Simmons, K.R., Caffrey, J.L., Phillips, J.L., Abel, J.H. \& Niswender, G.D. (1976) A simple method for preparing suspensions of luteal cells. Proc. Soc. exp. Biol. Med. 152, 366-371.

Speroff, L. \& Ramwell, P.W. (1970) Prostaglandin stimulation of in-vitro progesterone synthesis. J. clin. Endocr. Metab. 30, 345-350.

Received 22 June 1982 